ACTA UNIVERSITATIS NICOLAI COPER NICI

DOI: http://dx.doi.org/10.12775/AUNC_ECON.2015.016

EKONOMIA XLVI nr 2 (2015) 247-257

Pierwsza wersja złożona 3 października 2015

e-ISSN: 2392-1269

Końcowa wersja zaakceptowana 10 grudnia 2015

p-ISSN: 2080-0339

Weronika Wójcik, Agnieszka Generowicz*

\title{
INNOWACYJNA METODA ZAGOSPODAROWANIA ODPADÓW ORGANICZNYCH NA PRZYKŁADZIE WYBRANEJ GMINY WIEJSKIEJ
}

Z a r y s tre ści. Wermikompostowanie jest to technologia znana, choć nie jest popularna, jako technologia unieszkodliwiania odpadów. Aczkolwiek stworzenie odpowiednich warunków pracy dla dżdżownic, niesie za sobą szereg korzyści. Główną korzyścią są oczywiście względy finansowe, czyli niski koszt budowy i eksploatacji instalacji. Ponadto, z punktu widzenia środowiskowego, proponowana metoda zagospodarowania odpadów biodegradowalnych i osadów ściekowych, przy odpowiednim prowadzeniu procesu, nie powoduje emisji hałasu, zanieczyszczeń do atmosfery, nie wpływa na wody powierzchniowe, podziemne oraz gleby.

S ł o w a k l u c z o w e: odpady biodegradowalne, kompostowanie, wermikompostowanie.

K 1 a s y fik a c j J E L: Q51, Q53, Q55.

\section{WSTĘP}

W myśl znowelizowanej ustawy z 1 lipca 2011 r. o zmianie ustawy o utrzymaniu czystości i porządku w gminach oraz niektórych innych ustaw, gminy są zobligowane do organizacji zbiórki i unieszkodliwiania odpadów komunalnych w taki sposób, by ograniczyć masę odpadów komunalnych ulegających biodegradacji przekazywanych do składowania do poziomu 35\% ich całkowitej masy z roku 1995 (do 16 lipca 2020 roku).

\footnotetext{
* Adres do korespondencji: Agnieszka Generowicz, Politechnika Krakowska im. Tadeusza Kościuszki, Wydział Inżynierii Środowiska, ul. Warszawska 24, 31-155 Kraków, e-mail: agenerowicz@pk.edu.pl.

(C) 2015 Uniwersytet Mikołaja Kopernika. All rights reserved. http://www.aunc.ekonomia.umk.pl
} 
Tradycyjny proces kompostowania może być stosowany do odpadów zielonych z terenów zieleni miejskiej, roślinnych odpadów z targowisk, odpadów komunalnych organicznych oraz osadów ściekowych. Kompost to produkt nadający się do wykorzystania, zawierający próchniczotwórcze substancje organiczne, typowe substancje humusowe oraz składniki pokarmowe roślin. Jego jakość zależy od właściwości surowców oraz reżimu technologicznego prowadzonego procesu.

Proces wermikompostowania jest technologią znaną, opisaną w literaturze, choć dotychczas stosowaną jedynie w skali laboratoryjnej oraz pilotażowej. Wynika to prawdopodobnie z konieczności stworzenia odpowiednich warunków pracy dla dżdżownic, ich ciągłej kontroli oraz stabilizacji procesu, co wydaje się być niezwykle trudne, szczególnie w tak dynamicznie zmieniającym się środowisku, jakim są odpady biodegradowalne i osady ściekowe. W związku z tym, opisywana technologia, jest innowacyjną metodą procesu recyklingu organicznego odpadów biodegradowalnych, w tym osadów ściekowych, przy użyciu wermikultur.

Według danych literaturowych, użycie wermikultur gwarantuje możliwość przetworzenia bioodpadów wraz z osadami ściekowymi, w sposób umożliwiający uzyskanie dojrzałego kompostu, o znanym i akceptowalnym składzie, właściwościach fizykochemicznych oraz stanie sanitarnohigienicznym. W artykule przedstawiano możliwości ograniczania ilości odpadów biodegradowalnych, opierając się o bilans strumienia tych odpadów w wybranej jednostce samorządu terytorialnego.

\section{POJĘCIE ODPADÓW ORGANICZNYCH I OSADÓW ŚCIEKOWYCH}

Odpady organiczne, inaczej odpady biodegradowalne, stanowią grupę odpadów, które przy udziale mikroorganizmów ulegają rozkładowi - w warunkach tlenowych, bądź beztlenowych. Najbardziej charakterystyczną grupę tych odpadów stanowią powszechnie znane odpady powstałe w wyniku pielęgnacji terenów zielonych (np. ścięte trawy, liście, ścięte gałęzie, itp.) oraz tzw. odpady kuchenne (resztki żywności, czy resztki z przygotowania żywności, odpady po owocach i warzywach, itp.). Ale znaczną grupę odpadów biodegradowalnych stanowią również osady ściekowe, które przy zastosowaniu odpowiednich procesów można w sposób biologiczny przetworzyć jako kompost, możliwy do wykorzystania rolniczego.

W związku z faktem, iż w naszym kraju wzrasta ilość oczyszczalni ścieków, oczyszczalnie ścieków są modernizowane i rozbudowywane, jak również rozbudowywana jest wciąż sieć kanalizacji sanitarnej wzrasta ilość powstających osadów ściekowych. W myśl ustawy o odpadach, przez ko- 
munalne osady ściekowe rozumie się osady ściekowe pochodzące z oczyszczalni ścieków z komór fermentacyjnych oraz innych instalacji do oczyszczania ścieków komunalnych, jak również z oczyszczania innych ścieków o składzie zbliżonym do składu ścieków komunalnych. Największą ilość powstających osadów ściekowych stanowią osady ściekowe z komunalnych oczyszczalni ścieków komunalnych. Według danych GUS, w 2013 roku powstało 540 tys. Mg s.m./rok osadów ściekowych (Wydro i inni, 2014), a prognozy wskazują, iż systematycznie ilość osadów ściekowych będzie rosła (Rocznik Statystyczny 2004-2013). Szacuje się, że od 2018 roku będzie wytwarzanych ponad 700 tys. Mg s.m./rok osadów ściekowych (Bień i inni, 2011).

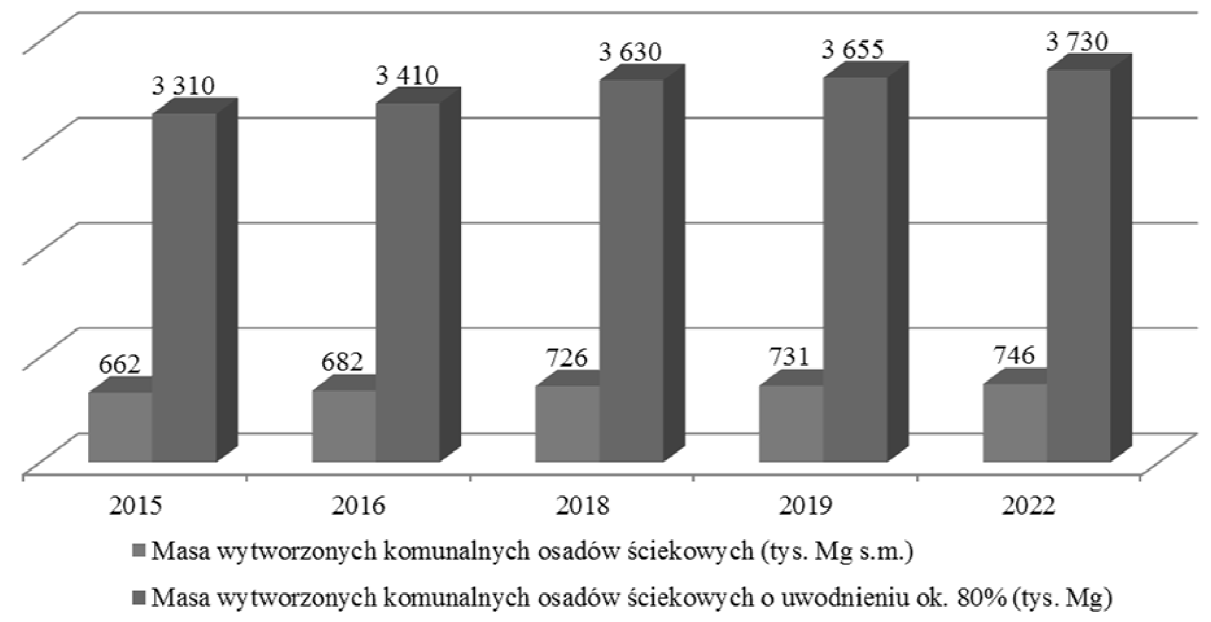

Rysunek 1. Prognoza wytwarzania komunalnych osadów ściekowych do 2022 roku dla Polski

Źródło: opracowanie własne.

Ale dość problematyczną grupę osadów ściekowych, stanowią osady z oczyszczalni przemysłowych. Niestety te zazwyczaj zawierają w swoim składzie metale ciężkie, oraz inne substancje niebezpieczne.

\section{UWARUNKOWANIA PRAWNE}

$\mathrm{Z}$ dniem wejścia w życie Rozporządzenia Ministra Gospodarki z dnia 8 stycznia 2013 roku w sprawie kryteriów oraz procedur dopuszczania odpadów do składowania na składowisku odpadów danego typu (DzU, 2013, poz. 38) określa się w $\$ 6.4$ oraz w załączniku nr 4 do tego rozporządzenia kryte- 
ria dopuszczania do składowania na składowisku odpadów innych niż niebezpieczne i obojętne. Między innymi wytyczne te dotyczą odpadów o kodzie 1908 05, czyli ustabilizowanych komunalnych osadów ściekowych. Jeśli komunalne osady ściekowe nie spełnią wymagań kryterialnych zapisanych w tabeli załącznika $\mathrm{nr} 4$, to, zgodnie z treścią $\$ 7$, nie będą mogły być z dniem 1 stycznia 2016 roku składowane na składowiskach odpadów innych niż niebezpieczne i obojętne. Niestety, zgodnie z posiadaną wiedzą praktyczną, ani ustabilizowane, ani nieustabilizowane osady ściekowe nie są w stanie spełnić wymagań kryterialnych zapisanych w tabeli załącznika nr 4. W związku z tym faktem z dniem 1 stycznia 2016 roku pojawi się gigantyczny problem dla oczyszczalni ścieków, które nie będą mogły, jak to dotychczas było stosowane, składować osadów ściekowych na składowiskach odpadów. Użycie słowa gigantyczny problem nie jest w zaistniałej sytuacji nieprzemyślane, gdyż wg danych GUS, dotychczas $81 \%$ powstających osadów ściekowych jest zagospodarowywane poprzez składowanie (Pająk, 2014; Bień, 2012; Wieremiej i inni, 2015).

W celu wsparcia realizacji zadań jednostek samorządu terytorialnego w zakresie osiągnięcia wymaganych poziomów redukcji odpadów biodegradowalnych, proponuje się przygotowanie instalacji umożliwiającej odzysk i unieszkodliwianie osadów ściekowych oraz odpadów biodegradowalnych z wykorzystaniem kultur dżdżownic. Realizacja projektu przewiduje rozwiązanie problemu wymaganych poziomów odzysku i recyklingu organicznego w danym regionie, jak również podjęcie problemu unieszkodliwiania osadów ściekowych.

\section{WŁAŚCIWOŚCI OSADÓW ŚCIEKOWYCH}

Skład i właściwości osadów ściekowych jest bardzo zróżnicowany. Ale charakteryzując pod względem fizycznochemicznym oraz mikrobiologicznym osady ściekowe, należy dokonać analizy zawartości substancji organicznych, składników nawozowych (przede wszystkim azot, fosfor i potas, metali ciężkich, toksycznych związków organicznych i mineralnych oraz organizmów chorobotwórczych (Malej, 2000). Do najbardziej charakterystycznych parametrów należą:

- zróżnicowane uwodnienie 80-55\% dla osadów odwodnionych, poniżej $10 \%$ po termicznym suszeniu,

- wysoka zawartość związków organicznych (około 75-85 \% suchej masy dla osadów nieustabilizowanych, 45-55\% dla osadów ustabilizowanych), 
- wysoka zawartość związków azotu (2-7\% s.m.), niższa związków fosforu i potasu,

- zróżnicowana zawartość metali ciężkich,

- zróżnicowany stopień zagrożenia sanitarnego.

W zależności od kierunku zagospodarowania osadów ściekowych (wykorzystanie rolnicze, składowanie na składowiskach, poddawanie obróbce termicznej, kompostowanie), osady ściekowe muszą cechować pewne parametry fizyko-chemiczne. Dla osadów ściekowych, które planowane są do wykorzystania rolniczego, decydują: jakość, skład oraz ich pochodzenie. Konieczne jest również wzięcie pod uwagę ewentualnego obciążenia zapachowego. Ponadto, odpady przeznaczone do wykorzystania rolniczego muszą być pozbawione organizmów chorobotwórczych. W przypadku planowanego wykorzystania osadów ściekowych w procesach termicznych, bądź też do ewentualnego ich składowania, kluczową rolę odgrywają właściwości w zakresie płynności osadów ściekowych. Odpady te powinny w takiej sytuacji charakteryzować się możliwie niskim uwodnieniem. Uwodnienie jest również ważne, z punktu widzenia aspektów ekonomicznych oraz poprawy wartości opałowej osadów. W procesie kompostowania, kluczową rolę odgrywają substancje toksyczne oraz niebezpieczne.

\section{WERMIKOMPOSTOWANIE, JAKO MOŻLIWY ELEMENT GOSPODARKI OSADAMI ŚCIEKOWYMI}

W zaistniałej prawnej sytuacji poszukuje się innowacyjnych metod i instalacji służących do możliwie optymalnego zagospodarowania osadów ściekowych. Kluczową rolę w tym wypadku odgrywają względy ekonomiczne. W tym aspekcie należałoby przeanalizować proces wermikompostowania. Jest to proces znany w literaturze, ale dość rzadko stosowany, ze względu na wymagania technologiczne w stosunku do wermikultury.

W literaturze istnieją przykłady dotyczące zastosowania dżdżownic do kompostowania osadów ściekowych w technologiach mleczarskich, papierniczych, tekstylnych. Niewiele jest danych dotyczących przetwarzania w technologii wermikompostowania odpadów komunalnych zmieszanych w rożnym stosunku z odpadami innymi niż komunalne, osadami ściekowymi i komponentami poprawiającymi jakość prowadzonego procesu np. zeolitami. Wyniki doświadczeń wskazują jednoznacznie, że działanie nawozowe kompostów i wermikompostów jest równorzędne $\mathrm{z}$ działaniem obornika, a w doświadczeniach wieloletnich występuje korzystny efekt następczy tych nawozów, także w odniesieniu do właściwości gleb. Niewątpliwie, jedną z zalet biologicznego przetwarzania odpadów wydaje się możliwość ela- 
stycznego przygotowania wsadu mieszanki. Natomiast poprzez odpowiednie zamodelowanie wsadu, możliwe jest pozyskanie dojrzałego kompostu, o odpowiedniej, pożądanej klasie, bądź kompostu posiadającego właściwości nawozowe - zgodnie z wymaganiami zawartymi w Rozporządzeniu Ministra Rolnictwa i Rozwoju Wsi z dnia 18 czerwca 2008 r. w sprawie wykonania niektórych przepisów ustawy o nawozach i nawożeniu. Istotna jest również kontrola procesu, głównie poprzez wskaźnik $\mathrm{AT}_{4}$, dający obraz etapu procesu.

Również, wstępnie prowadzone badania nad procesem wermikompostowania przez Politechnikę Krakowską, wykazują, iż proces technologiczny wykorzystujący kultury dżdżownic z rodziny Lumbricidae tj. Dendrobaena veneta i Eisenia foetida, dla recyklingu organicznego osadów ściekowych, przy wykorzystaniu komponentów uzupełniających proces w postaci różnych, wydzielonych selektywnie frakcji biodegradowalnych odpadów oraz zeolitów umożliwia otrzymanie pełnowartościowego materiału, nadającego się do rekultywacji i rozprowadzenia na powierzchni ziemi (Wójcik i inni, 2015).

W wyniku prowadzonych procesów, otrzymuje się redukcję masy wsadu do wermikompostowania przy użyciu wermikultury na poziomie około $65 \%$ wagowych. Otrzymany produkt, tzw. wermikompost, kompost dżdżownicowy lub biohumus to nawóz organiczny, którego właściwości zależą od wielu czynników takich jak: skład substancji pokarmowych, zagęszczenia hodowlanych dżdżownic oraz czasu ich przebywania w poszczególnych warstwach pokarmowych (Elvira i inni, 1998; Ndegwa,2000).

Niestety kompost z osadów ściekowych może zawierać znaczne ilości metali ciężkich. Poprawę własności nawozowych kompostów można uzyskać przez wykorzystanie $\mathrm{w}$ procesie kompostowania wybranych gatunków dżdżownic, co mimo stwierdzonych trudności ma zalety w odniesieniu do poprawy jakości materiału rekultywacyjnego. Zastosowywanie dżdżownic w procesie technologicznym prowadzi do eliminacji metali ciężkich z kompostu, ponieważ Eisenia foetida ma zdolność kumulowania tych pierwiastków. Opisane w literaturze wyniki badań świadczą o dobrych właściwościach nawozowych badanych kompostów uzyskiwanych zarówno z odpadów organicznych pochodzenia komunalnego, jak i osadów ściekowych. W wynikach badań zauważyć można dosyć istotne różnice w zawartości pierwiastków biogennych i ich form w poszczególnych kompostach i wermikompostach. Oczywiście wpływ na to mają zastosowane parametry technologiczne i sposób prowadzenia procesu kompostowania. 


\section{BILANS GOSPODARKI OSADAMI ŚCIEKOWYMI W GMINIE WIEJSKIEJ, POPRZEZ ICH WERMIKOMPOSTOWANIE}

Zgodnie z ustawą z 1 lipca 2011 roku o zmianie ustawy o utrzymaniu czystości i porządku w gminach oraz niektórych innych ustaw, gminy są zobligowane do organizacji zbiórki i unieszkodliwiania odpadów komunalnych w taki sposób, by ograniczyć masę odpadów komunalnych ulegających biodegradacji przekazywanych do składowania do poziomu 35\% ich całkowitej masy z roku 1995 (do 16 lipca 2020 roku). W tej sytuacji, w przypadku konieczności redukcji strumienia odpadów komunalnych, jak również ze względu na zbliżający się zakaz składowania osadów ściekowych, na podstawie wstępnych założeń i kalkulacji oraz wyników badań prowadzonych na Politechnice Krakowskiej przy współpracy z Firmą ProdukcyjnoHandlowo-Usługową „KOMPOSAD” Bernadeta Jemioło Spółka Jawna, dokonano wstępnego bilansu osadów ściekowych i odpadów biodegradowalnych w gminie wiejskiej.

Charakteryzowana gmina wiejska, jest gminą posiadającą ok. 14 tys. mieszkańców. Przyjmuje się ilość powstającego osadu na poziomie 1020 $\mathrm{Mg} /$ rok. Ponadto, w celu poprawy parametrów kompostu możliwe jest wykorzystanie innych odpadów biodegradowalnych. Zgodnie z Wytycznymi dotyczacymi wymagań dla procesów kompostowania, fermentacji i mechaniczno - biologicznego przetwarzania odpadów, surowcami w procesach technologicznych mogą być odpady z podgrup $1501,2001,2002$ oraz 2003 . Kierując się ogólnymi zaleceniami zawartymi w wymaganiach BAT oraz polskimi normami i normatywami, a także wynikami badań efektywności przetwarzania odpadów w różnych instalacjach, znając wymagane parametry jakościowe, możliwe jest przeprowadzenie procesu z mieszanki, w skład której wchodzić mogą odpady ulegające biodegradacji z innych grup niż komunalne (wg katalogu odpadów) tj. 02 01, 02 02, 02 03, 02 04, 02 05, 02 06, 02 07, 03 01, 03 03, 04 01, 04 02, 15 01, 16 03, 17 02, 19 06, 19 08, 19 09, 19 12. Mając powyższe na uwadze, założono wykorzystanie odpadów biodegradowalnych (innych niż osady ściekowe) na poziomie ok. $1530 \mathrm{Mg} /$ rok. Do oszacowania wydajności instalacji przyjęto gęstość nasypową wsadu do wermikompostowania na poziomie $1 \mathrm{Mg} / 1 \mathrm{~m}^{3}$. Wg założeń technologicznych, szacuje się efektywność pracy wermikultur określoną w oparciu o następujące dane:

- gęstość nasypowa $1,0 \mathrm{~m}^{3}$ wsadu przyjęto na poziomie $1,0 \mathrm{Mg}$,

- ilość cykli technologicznych w ciągu roku (,dokarmiania” wermikultury) - ok. 30 razy,

- powierzchnia czynna złóż wermikultur ok. $1200 \mathrm{~m}^{2}$. 
Ze względu na warunki życia wermikultury, optymalne warunki żerowania to $0,1-0,15 \mathrm{~m}$. W takim systemie należy dokarmiać wermikulturę. Przy założonych 30 cyklach technologicznych przewiduje się, że rocznie kompostowaniu poddawane będzie ok. $3,0 \mathrm{~m}^{3} / \mathrm{m}^{2}$ wsadu. Wsad składał się będzie z:

- ok. $60 \%$ odpadów biodegradowalnych o gęstości nasypowej 0,75 $\mathrm{Mg} / \mathrm{m}^{3}$,

- ok. $40 \%$ osady ściekowe o gęstości nasypowej $0,95 \mathrm{Mg} / \mathrm{m}^{3}$,

- gęstość nasypowa wsadu do kompostowania wermikulturami 0,83 $\mathrm{Mg} / \mathrm{m}^{3}$.

Oczywiście skład ten został dobrany w taki sposób, aby osiągnąć możliwie duży stopień redukcji odpadów biodegradowalnych. Jak również, przyjęcie takich proporcji powinno zagwarantować otrzymanie kompostu bez ponadnormatywnego występowania metali ciężkich. Przy powyższych założeniach, szacuje się, iż procesowi wermikompostowania w ciągu roku ulegnie ok. $2,5 \mathrm{Mg} / \mathrm{m}^{2}$ odpadów (mieszanki osadów ściekowych i odpadów biodegradowalnych). Przy założeniu powierzchni pryzm na poziomie ok. 1200 $\mathrm{m}^{2}$, osiąga się wydajność instalacji na poziomie $3000 \mathrm{Mg} /$ rok. Oczywiście jest to wartość szacunkowa, ale przygotowana w oparciu o wstępnie przeprowadzone badania. Rzeczywista efektywność procesu będzie każdorazowo weryfikowana i zależna będzie od parametrów wsadu. Ponadto, zaobserwowana redukcja odpadów wynikająca z zastosowania procesu wermikompostowania przewidywana jest na poziomie $60-70 \%$. Przy założeniu najniekorzystniejszych warunków, tj. redukcji odpadów na poziomie ok. $60 \%$, przy założonej wydajności wynoszącej $3000 \mathrm{Mg} / \mathrm{rok}$, możliwe jest wyprodukowanie wermikompostu w ilości ok. $1800 \mathrm{Mg} /$ rok.

Jak wynika z powyższej analizy, czynnikiem determinującym wydajność instalacji jest ilość dostarczonych odpadów. Niestety czynnikiem ograniczającym jest powierzchnia, konieczna do wykorzystania pod budowę łóż do wermikompostowania oraz niezbędnej infrastruktury technicznej.

\section{PODSUMOWANIE}

Jak wynika z powyższej analizy, proces wermikompostowania niesie za sobą czynnik ograniczający, w postaci niezbędnej powierzchni. Dlatego też, rozwiązanie to proponuje się, jako element gospodarki odpadami biodegradowalnymi oraz osadami ściekowymi, w jednostkach osadniczych o charakterze wiejskim, oraz na zbliżonym (bądź mniejszym) poziomie produkcji osadów ściekowych i odpadów biodegradowalnych niż założony w powyższej analizie. Oczywiście w przypadku dysponowania tylko i wyłącznie osadami ściekowymi o charakterze komunalnym, w których nie odnotowuje się 
przekroczeń dopuszczalnych norm metali ciężkich, możliwe jest prowadzenie procesu wermikompostowania większej ilości osadów ściekowych (zmiana stosunku odpadów wsadowych). Wymaga to jednak ścisłej kontroli wsadu i procesu.

Opisany proces wermikompostowania niesie za sobą szereg korzyści. Główną korzyścią są oczywiście względy finansowe, czyli niski koszt budowy i eksploatacji instalacji. Ponadto, z punktu widzenia środowiskowego, proponowana metoda zagospodarowania odpadów biodegradowalnych i osadów ściekowych, przy odpowiednim prowadzeniu procesu, zgodnym z założeniami projektowymi, nie powoduje emisji hałasu, zanieczyszczeń do atmosfery, nie wpływa na wody powierzchniowe, podziemne oraz gleby. Jest, bowiem w pełni naturalna, co jest oczywiste, ze względu na wykorzystanie organizmów żywych - wermikultur, dla której dąży się do zoptymalizowania naturalnych warunków bytowania.

Niestety w przypadku procesu wermikompostowania występuje też kilka czynników ryzyka, które mocno wpływają na decyzyjność oraz często są zniechęcające dla potencjalnych wytwórców osadów ściekowych lub jednostek zajmujących się ich unieszkodliwianiem. Kluczowym problemem jest niejednorodność osadów ściekowych. To niestety determinuje dalsze postępowanie z osadem ściekowym i odpadami biodegradowalnym, stąd znajomość odpadów biodegradowalnych i wiedza na temat przewidywalności procesu odgrywa tutaj priorytetową rolę. Ważna jest również znajomość przepływu strumienia odpadów biodegradowalnych w wiejskich jednostkach osadniczych, ze względu na konieczność ciągłego dokarmiania wermikultury. Niestety nie jest to proces możliwy do sterowania komputerowo, dlatego konieczne są odpowiednie kompetencje zespołu zajmującego się prowadzeniem procesu, wynikające $\mathrm{z}$ znajomości i przewidywalności wermikultury, zespół powinien posiadać również wiedzę oraz doświadczenie z zakresu gospodarki odpadami, funkcjonowania systemu gospodarki oraz prawa obowiązującego w gospodarce odpadami.

Podsumowując, zastosowana wieloaspektowa technologia wermikompostowania umożliwia osiągnięcie wymaganych poziomów odzysku oraz zagospodarowanie powstających w jednostce osadniczej osadów ściekowy. Wyżej opisane sposoby postępowania $\mathrm{z}$ odpadami biodegradowalnymi dzięki zastosowaniu nowoczesnych rozwiązań techniczno-organizacyjnych, w znaczącym stopniu ograniczają powstawanie odpadów, a ich zagospodarowanie stanowi integralną część kompleksowego systemu zarządzania odpadami biodegradowalnymi. 


\section{LITERATURA}

Bień J., Neczaj E., Worwąg M., Grosser A., Nowak D., Milczarek M., Janik M. (2011), Kierunki zagospodarowania osadów w Polsce po roku 2013, „Inżynieria i Ochrona Środowiska", 14(4), 375-384.

Bień J.D. (2012), Zagospodarowanie komunalnych osadów ściekowych metodami termiczny$m i$, ,Inżynieria i Ochrona Środowiska”, 15(4), 439-449.

Elvira C., Sampedro L., Benitez R., Nogales R. (1998), Vermicomposting of sludges from paper mill and dairy industries with Eisenia Andrei: A pilot - scale study, „Bioresource Technology", 63, 205-211.

Malej J. (2000), Właściwości osadów ściekowych oraz wybrane sposoby ich unieszkodliwiania i utylizacji, ,Rocznik Ochrona Środowiska”, 2, 69-101.

Ndegwa P. (2000), Effects of stocking density and feeding rate on vermicomposting of biosolid, „Bioresource Technology”, 71, 5-12.

Obwieszczenie Marszałka Sejmu Rzeczypospolitej Polskiej z dnia 13 września 2013 r. w sprawie ogłoszenia jednolitego tekstu ustawy o utrzymaniu czystości $i$ porzadku w gminach (DzU, 2013, poz. 1399).

Pająk T. (2014), Uwarunkowania technologiczne, ekonomiczne i prawne termicznego przeksztatcania osadów ściekowych w Polsce, „Gaz, Woda i Technika Sanitarna 2014”, 4, $154-158$

Pająk T. (2014), Termiczne przeksztatcanie osadów ściekowych wobec wyzwań roku 2016, „Inżynieria i Ochrona Środowiska”, 17(3), 363-376.

Rocznik Statystyczny Ochrona Środowiska 2004-2013.

Rozporządzenie Ministra Środowiska z dnia 6 lutego 2015 w sprawie komunalnych osadów ściekowych (DzU, 2015, poz. 257).

Ustawa z dnia 14 grudnia 2012 o odpadach (DzU, 2013, poz. 21 z późniejszymi zmianami).

Wieremiej W., Kuziemska B., Pieniak-Lendzion K., Trębicka J., Wyrębek H. (2015), Prawne aspekty przyrodniczego wykorzystania osadów ściekowych, „Zeszyty Naukowe Uniwersytetu Przyrodniczo-Humanistycznego w Siedlcach”, seria: „Administracja i Zarządzanie", 104.

Wójcik W., Generowicz A., Kryłów M. (2015), Wermikompostowanie biodegradowalnych odpadów i osadów ściekowych, „Przemysł Chemiczny”, 130-133, DOI: http://dx.doi.org/10.15199/62.2015.5.20.

Wydro E., Wołejko E., Butarewicz A., Łoboda T. (2014), Warunki i możliwości wykorzystania komunalnych osadów ściekowych do nawożenia trawników miejskich, EKO-DOK.

Wytyczne dotyczące wymagań dla procesów kompostowania, fermentacji i mechaniczno biologicznego przetwarzania odpadów (według stanu prawnego na dzień 15 grudnia 2008 roku), Warszawa, 2008.

\section{AN INNOVATIVE METHOD OF USING ORGANIC WASTE ON THE EXAMPLE OF SELECTED RURAL COMMUNE}

A b s t r a ct. Vermicomposting is a known technology, although it is not popular as a technology for waste disposal. However, there are a number of benefits that may result when creating the appropriate working conditions for earthworms. The main benefit concerns, of course, financial reasons, namely the low cost of the construction and functioning of installation. Moreover, from the environmental point of view the proposed method of biodegradable 
waste and sewage sludge, with proper conduct of the process, does not cause noise pollution, atmospheric pollution, does not affect the surface water, groundwater and soil.

K e y w o r d s: biodegradable waste, composting, vermicomposting. 
